\title{
Development and Possibilities for Close-to-Nature Forest Resource Management in Hungary
}

\author{
Béla LETT ${ }^{\mathrm{a}^{*}}$ - János GÁL ${ }^{\mathrm{a}}$ - Magdolna STARK ${ }^{\mathrm{a}}$ - Norbert FRANK ${ }^{\mathrm{b}}$ \\ ${ }^{a}$ Institute of Forest Resource Management and Rural Development, \\ Faculty of Forestry, University of West Hungary, Sopron, Hungary \\ ${ }^{\mathrm{b}}$ Institute of Silviculture and Forest Protection, Faculty of Forestry, \\ University of West Hungary, Sopron, Hungary
}

\begin{abstract}
Legal regulations of the activities of forest managers were fundamentally changed by the legislature of the past decade, and little is known about the actual change in forest management practices. Based on the data collected by the State Forest Service, this study investigates the changes of the past 15 years and presents the influencing factors, primarily the species and sectorial characteristics and differences

In the study both the area of final cuts and regenerations are presented by modes, sectors and species. The main factors influencing forest resource management are site (which can be modified by climate change) and the corresponding species or stand type. Based on these possibilities, close-tonature forest management can be evaluated on a more realistic basis. The sum and average values for the whole country are too general; the country consists of sectors with different forest resource management properties.
\end{abstract}

\section{forest resource management / final cutting methods / regeneration methods}

Kivonat - A természetközeli erd vagyon-gazdálkodás fejl dése és lehet ségei. Az elmúlt évtized jogi el írásai és igazgatási eljárása alapvet en megváltoztatták az erd gazdálkodók tevékenységének szabályozását, amely a gyakorlatot is módosítja, ennek mértékér 1 azonban nem sokat tudunk. A tanulmány az Erdészeti Igazgatóság által gy jtött és közzétett adatok alapján mintegy 15 év változását vizsgálja és bemutatja a ható tényez ket, els sorban a regionális és a szektorális sajátosságokat és különbségeket.

A véghasználat területét és fatérfogatát használati módonként, régiónként, szektoronként és fafajonként mutatjuk be, az erd felújításokat (els kivitel és befejezett erd sítés) felújítási módonként, régiónként, szektoronként és fafajonként szemléltetjük. A (klímaváltozással módosuló) term hely, az annak megfelel fafaj bizonyul az erd vagyon-gazdálkodást meghatározó legfontosabb tényez nek, így a természetközeli erd vagyon-gazdálkodás lehet ségeit is reálisabban ítélhetjük meg (amely a további változások megtervezésénél és el írásánál hasznot jelenthet). Az országos összesen és az átlagok magyarázó ereje nagyon kicsi, az ország teljesen máshogy m köd erd vagyon-gazdálkodású régiókból áll, kívánatos a regionális erd vagyon-gazdálkodási programok készítése.

erd vagyon-gazdálkodás / fahasználati eljárások / erd felújítási módok

\footnotetext{
* Corresponding author: lettb@emk.nyme.hu; H-9400 SOPRON, Bajcsy-Zs. u. 4., Hungary
} 


\section{INTRODUCTION}

The law LIV of 1996 regarding forests put forest management on new foundations in the period after the change of the political system. This period was closed by the law XXXVII of 2009 , also a forest law, which introduced a new attitude towards ecological sustainability of forest management.

Several studies were published about close-to-nature forest management (Solymos 2000), siviculture (Frank 2012), about the change of the structure of forest resources (Lett - Stark 2013), and about regional forest management (Lett - Stark 2014).

The initiative called „Past and Future” started as a consultation among forestry professionals on close-to-nature forest management, which then resulted in a series of publications. It started with the publication of the presentations of the rség Forestry Days, which deals mainly with the selection system in small forest properties in the Vend area (Lett et al. 2009). The publication was a success; it had a positive effect on the opinion of experts and the next publication „Past and Future II: from clearcut to selection system” dealt with the experience of scientists, educators, and administrators in separate chapters. The study also raised questions and listed possible failures in connection with intruducing the selection system (Lett et al. 2010). The topic became even more interesting as the new Forestry Law (Law XXXVII of 2009) made the introdutction of the selection system compulsory in an increasing proportion after every 10 year period in the state forests.

The gathered experience was discussed on the $2^{\text {nd }}$ Meeting of Forestry Economists and the studies were published in a publication "Past and Future III - The selection system from the viewpoit of forest managers" (Lett - Schiberna 2012)

The publication "Past and Future IV - Sustainability, close-to-nature management, control by the society" was compiled based on the presentations of another conference (Forest forum in K szeg) (Gyöngyössy 2012).

Theoretical questions of the new method are discussed in Schiberna et al. (2012); the practical economic investigations were summarized by Csépányi (2013). The investigations of the cost-benefit relations in transformation and selection systems (Marosi - Juhász 2012, 2014) also contributed to the general economic understanding of these systems.

The forestry law of 1996, with its ministerial decrees and regulations, completely changed the regulation of activities of forest managers, which then modified the everyday practice. Little is known about the scope of this change; therefore, we decided to make a preliminary analysis based on the data of the year 2000 .

To characterize forest resource management, we present the change of utilizations and regeneration modes in the first decade of the $21^{\text {st }}$ century (2000-2009/2010 and 2008/2009).

We consider year 2000 as a base so that changes can be made visible.

The combinations of utilization and regeneration modes are directly related to forest resource management concepts and are the distinctive characteristics of slivicultural regimes. This study puts emphasis on factors influencing silviculture, among which site and tree species combinations are of paramount importance. Due to the significant differenes between state and private forests with regards to these factors, the prospects of close-to-nature forest management are also different in these sectors.

\section{MATERIALS AND METHODS}

The study is based on the primary analysis of data published annually by Forestry Authority (ÁESZ; MGSZH; Forestry Directorate of NÉBIH): Report on afforestations and utilizations in the years 2000-2010. 
When analyzing forest resource management, combinations of timber utilization and regeneration modes are investigated. Forestry Authority prepared two lists about utilization-regeneration mode combinations in this period because of the changes in the legal regulation. Comparisions and data analysis were conducted with due regards to these differences.

As the basis for comparision, the year 2000 has been chosen, which is far enough from 1996 to allow time for the new regulations to take effect, and also far enough from 2009 to have a sufficient dataset to be analyzed. Of course some years bring random elements, but there are insufficient periods for calculating averages about the new forest resource management regulations, and the appearance and registration of first plantings also changes.

In this study the differences between public (state and community) and private ownership forms are also analyzed.

\section{PRODUCTION, PROTECTED AND NATURA 2000 FORESTS}

Because of the change in legal environment, we investigated the forest assets management in the new primary function categories.

The area of final cuttings in the production forests is double that of the protected and Natura 2000 forests (and nearly half of this area is black locust). Forest resource management (and its elements) is strongly influenced by the utilization of exploitable stands on protected and Natura 2000 areas in the next 10-20 years; the limiting regulations of their regeneration and the encouragements for species changes. One fifth of the allowable cut is black locust and poplar on the protected and Natura 2000 areas, which is another long term problem. A similar question is the role of conifers (spruce - lowland and barren lands, present situation and future vision); conifers on protected and Nature 2000 areas make up half of the area on production areas for the same species.

Because of the large difference in species proportions, the area and volume relations also show big differences among production and protected forests as shown in Table 1.

With the Natura 2000 designations (and with their interpretation by the authorities) the area of forest with non-production functions has practically doubled, and the proportion of stands with native species on protected/Natura2000 areas is higher than on production areas.

Besides the stock variables of forest management (forest area - FA, growing stock - GS) special attention is also given to the flow elements (area of cuttings - AC, volume of cuttings - VC). The allowable cut (final cuttings) is presented by the area and volume of stands designated for cutting in the next decade.

Another important question of Hungarian forest resource management is to what extent the allowable cut on protected and Natura2000 areas can be utilized.

Beech evokes strong emotions especially from nature conservationists and partly also from the general public. However, it is only important in smaller regions because its share in the forest cover and in the standing timber volume is low on national level. Because of the overwhelming proportion of the protection function in beech forests, the only way to make use of their timber yield is to apply close-to-nature silivicultural methods that are suitable for the protection goals. 
Table 1. Forest area and growing stock in 2010, as well as area and volume of final cutting 2000-2010 by species in production, protected and Natura 2000 forests in Hungary

\begin{tabular}{|c|c|c|c|c|c|c|c|c|}
\hline \multirow[b]{2}{*}{ Species } & \multicolumn{2}{|c|}{$\begin{array}{c}\text { Forest area } \\
\text { (FA) }\end{array}$} & \multicolumn{2}{|c|}{$\begin{array}{l}\text { Area of final } \\
\text { cutting (AC) }\end{array}$} & \multicolumn{2}{|c|}{$\begin{array}{c}\text { Growing stock } \\
\text { (GS) }\end{array}$} & \multicolumn{2}{|c|}{$\begin{array}{l}\text { Volume of final } \\
\text { cutting (VC) }\end{array}$} \\
\hline & $\begin{array}{l}\text { Produc- } \\
\text { tion } \\
\left(10^{3} \mathrm{ha}\right)\end{array}$ & $\begin{array}{c}\text { Protected } \\
\text { Natura } \\
\left(10^{3} \text { ha }\right)\end{array}$ & $\begin{array}{c}\text { Produc- } \\
\text { tion } \\
\left(10^{3} \mathrm{ha}\right)\end{array}$ & $\begin{array}{c}\text { Protected } \\
\text { Natura } \\
\left(10^{3} \text { ha }\right)\end{array}$ & $\begin{array}{l}\text { Produc- } \\
\text { tion } \\
\left(10^{6} \mathrm{~m}^{3}\right)\end{array}$ & $\begin{array}{c}\text { Protected } \\
\text { Natura } \\
\left(10^{6} \mathrm{~m}^{3}\right)\end{array}$ & $\begin{array}{l}\text { Produc- } \\
\text { tion } \\
\left(10^{3} \mathrm{ha}\right)\end{array}$ & $\begin{array}{c}\text { Protected } \\
\text { Natura } \\
\left(10^{3} \mathrm{ha}\right)\end{array}$ \\
\hline 1 Beech & 22.0 & 88.0 & 2.5 & 6.1 & 8.0 & 31.4 & 1.3 & 3.1 \\
\hline 2 Oak & 166.2 & 222.0 & 10.0 & 19.0 & 32.1 & 52.0 & 3.5 & 6.5 \\
\hline 3 Turkey oak & 102.2 & 104.1 & 12.1 & 11.5 & 22.1 & 23.1 & 3.8 & 3.6 \\
\hline 4 Other hardw. & 80.4 & 120.3 & 8.6 & 10.7 & 13.8 & 22.7 & 2.1 & 2.8 \\
\hline $5 \begin{array}{ll}\text { LRHW } \\
(1+2+3+4)\end{array}$ & 370.8 & 534.4 & 33.2 & 47.3 & 76.0 & 129.2 & 12.9 & 19.2 \\
\hline 6 Black locust & 376.6 & 70.3 & 74.7 & 7.2 & 39.6 & 8.5 & 11.8 & 2.6 \\
\hline 7 Hybrid popl. & 93.1 & 30.7 & 31.8 & 10.0 & 10.9 & 5.0 & 5.0 & 2.1 \\
\hline $\begin{array}{ll}8 & \text { Bl.l. }+ \text { Hyb.popl } \\
(6+7)\end{array}$ & 469.7 & 101.0 & 106.5 & 17.2 & 50.5 & 13.5 & 16.8 & 4.7 \\
\hline 9 Poplars & 46.3 & 27.2 & 8.1 & 4.7 & 6.6 & 5.9 & 1.9 & 1.6 \\
\hline 10 Other softw. & 43.8 & 56.0 & 6.6 & 8.2 & 9.4 & 13.8 & 1.9 & 1.3 \\
\hline 11 Conifers & 141.5 & 71.4 & 14.8 & 6.5 & 34.0 & 20.1 & 4.0 & 2.1 \\
\hline $\begin{array}{c}12 \text { Softw. +con. } \\
\quad(9+10+11)\end{array}$ & 231.6 & 154.6 & 29.5 & 19.4 & 50.0 & 39.8 & 7.8 & 5.0 \\
\hline $\begin{array}{l}13 \text { Non LRHW } \\
(8+12)\end{array}$ & 701.3 & 255.6 & 136.0 & 36.6 & 100.5 & 53.3 & 24.6 & 9.7 \\
\hline Total $(5+12)$ & $1,072.1$ & 789.9 & 169.3 & 84.0 & 176.5 & 182.5 & 35.2 & 25.5 \\
\hline
\end{tabular}

In the cases of black locust and hybrid poplar, more than 100 thousand hectares are under protection or Natura2000. Of course these forests are not the subject of protection, but they fall within protection zones. However, protection measures also affect them. These two species make up a considerable share in harvest volume and, thus, they also have a great financial impact on the forestry sector. It is difficult to measure how far they fall from closeto-nature state, and it is even more difficult to find ways through which close-to-nature silvicultural methods could be introduced in these plantations without the plantations losing their profitability. The attitude of nature protection is basically condemnatory and the problems can be handled on a very long time frame.

The proportion of coniferous stands has considerably diminished.Their state of health is critical; it is possible and necessary to replace these stands with other species.

There is a critical situation in the groups of oak, Turkey oak and other hardwoods where the proportion of production forests exceeds one-third and approaches one-half.

\section{FINAL CUTTING AND REGENERATION MODES}

\subsection{Area and volume of final cuttings by sector and cutting modes}

The combinations of final cutting and regeneration modes characterize forest resource management. Firstly, the data on final cuttings (and those of regeneration, which are nearly identical) is presented. Dataset is classified by sector (state and private) and modes of cut (clearcut and regeneration cut). 
At the flow data and especially at the area of final cuts (Table 2), but also at volume (Table 3) the possibilities of private forestry are considerable, particularly in black locust and hybrid poplar stands.

Table 2. Area of final cuttings $2000-2010$ (ha)

\begin{tabular}{|c|c|c|c|c|c|c|c|c|c|c|}
\hline Sector & $\begin{array}{c}\text { Clear- } \\
\text { cut }\end{array}$ & $\begin{array}{c}\text { Regen. } \\
\text { cut }\end{array}$ & $\begin{array}{l}\text { Shelt. } \\
\text { cut }\end{array}$ & $\begin{array}{l}\text { Final } \\
\text { cut total }\end{array}$ & $\begin{array}{l}\text { (Sel. } \\
\text { cut) }\end{array}$ & $\begin{array}{l}\text { (Stock } \\
\text { maint.) }\end{array}$ & $\begin{array}{l}\text { Unr. } \\
\text { cut }\end{array}$ & Oth. & Total & $\begin{array}{c}\text { Clear } \\
\text { cut } \\
\%\end{array}$ \\
\hline \multicolumn{11}{|c|}{2000} \\
\hline \multirow{2}{*}{$\begin{array}{l}\text { State + } \\
\text { community } \\
\text { Private }\end{array}$} & 8,211 & 3,465 & - & 11,676 & $*$ & $*$ & 108 & & 11,785 & 69.7 \\
\hline & 8,823 & 534 & - & 9,358 & $*$ & $*$ & 35 & & 9,392 & 93.9 \\
\hline \multirow[t]{2}{*}{ Total } & 17,034 & 3,999 & - & 21,034 & $*$ & $*$ & 144 & & 21,177 & 80.4 \\
\hline & 80.4 & 18.9 & - & 99.3 & $*$ & $*$ & 0.7 & & 100 & \\
\hline \multicolumn{11}{|c|}{2010} \\
\hline \multirow{2}{*}{$\begin{array}{l}\text { State }+ \\
\text { community } \\
\text { Private }\end{array}$} & 7,780 & 3,342 & 241 & 11,363 & $*$ & $*$ & 449 & & 11,812 & 65.9 \\
\hline & 9,356 & 792 & 41 & 10,188 & $*$ & $*$ & 48 & & 10,236 & 91.4 \\
\hline \multirow[t]{2}{*}{ Total } & 17,216 & 4,134 & 285 & 21,635 & $*$ & $*$ & 499 & & 22,134 & 77.8 \\
\hline & 77.8 & 18.7 & 1.3 & 97.7 & $*$ & $*$ & 2.3 & & 100.0 & \\
\hline
\end{tabular}

* Authorities do not assign area for regeneration obligation.

Source of data $\mathrm{MgSzH}$

Table 3. Volume of final cuttings by modes of cut and sectors $2000-2010\left(10^{3} \mathrm{~m}^{3}\right)$

\begin{tabular}{|c|c|c|c|c|c|c|c|c|c|c|}
\hline Sector & $\begin{array}{c}\text { Clear- } \\
\text { cut }\end{array}$ & $\begin{array}{c}\text { Regen. } \\
\text { cut }\end{array}$ & $\begin{array}{c}\text { Shelt. } \\
\text { cut }\end{array}$ & $\begin{array}{l}\text { Final } \\
\text { cut total }\end{array}$ & $\begin{array}{l}\text { (Sel. } \\
\text { cut) }\end{array}$ & $\begin{array}{l}\text { (Stock } \\
\text { maint.) }\end{array}$ & $\begin{array}{l}\text { Unr. } \\
\text { cut }\end{array}$ & Oth. & Total & $\begin{array}{c}\text { Clear } \\
\text { cut } \\
\%\end{array}$ \\
\hline \multicolumn{11}{|c|}{2000} \\
\hline \multirow{2}{*}{$\begin{array}{l}\text { State }+ \\
\text { community } \\
\text { Private }\end{array}$} & 2,017 & 1,252 & - & 3,269 & - & - & 322 & 39 & 3,630 & 55.6 \\
\hline & 1,627 & 125 & - & 1,752 & - & - & 104 & 22 & 1,878 & 86.6 \\
\hline \multirow[t]{2}{*}{ Total } & 3,644 & 1,377 & - & 5,021 & - & - & 426 & 61 & 5,508 & 66.2 \\
\hline & 66.1 & 25.0 & - & 91.1 & - & - & 7.8 & 1.1 & 100 & \\
\hline \multicolumn{11}{|c|}{2010} \\
\hline \multirow{2}{*}{$\begin{array}{l}\text { State }+ \\
\text { community } \\
\text { Private }\end{array}$} & 1,801 & 1,209 & 95 & 3,107 & 41 & 1 & 456 & 31 & 3,635 & 49.5 \\
\hline & 1,813 & 2,370 & 12 & 2,062 & 4 & 5 & 99 & 18 & 2,187 & 82.9 \\
\hline \multirow[t]{2}{*}{ Total } & 3,629 & 1,447 & 107 & 5,184 & 45 & 6 & 556 & 49 & 5,841 & 62.1 \\
\hline & 62 & 24.8 & 1.8 & 88.8 & 0.8 & 0.1 & 9.5 & 0.8 & 100 & \\
\hline
\end{tabular}

Source of data MgSzH

Cutting modes in 2010 were extended with modes which were not present in the statistics in 2000 (shelterwood cut, selection cut, growing stock maintaining cut). In the statistics of 2010, the new elements of utilization, the volume of which is minimal, appeared. Shelterwood cut generates obligation for regeneration; for selection cut and growing stock maintaining cut - the volume of which is negligible - the authorities do not assign obligation for regeneration.

The basic consequence is the change of proportion of clearcuts which is similar in terms of area and volume, but is different in magnitude (because of the already mentioned difference in specific volume). Regeneration cuts did not increase considerably in volume or in proportion; shelterwood cut, selection cut, and growing stock maintaining cuts just appeared recently and are in the phase of planning. The numbers of utilization (and consequently those of regeneration) show a steadiness typical for sustainable management and we cannot expect a sudden change in volume because of the strong determination. 


\subsection{Volume of final cuttings 2000-2010}

Comparing the data from 2000 and 2010, no considerable shift in area, volume, proportions, or sectors can be observed, but a little change is noticeable from clearcut to regeneration cut (regeneration cut also increased in private sector). Clearcut is still determining in private forestry. Figure 1 shows the proportions, their differences, and change in time.

The difference between the sectors in final cut - regeneration modes is considerable because of the stable difference in the forest resource of the state and private sector; changing this is a slow process determined by many other factors.

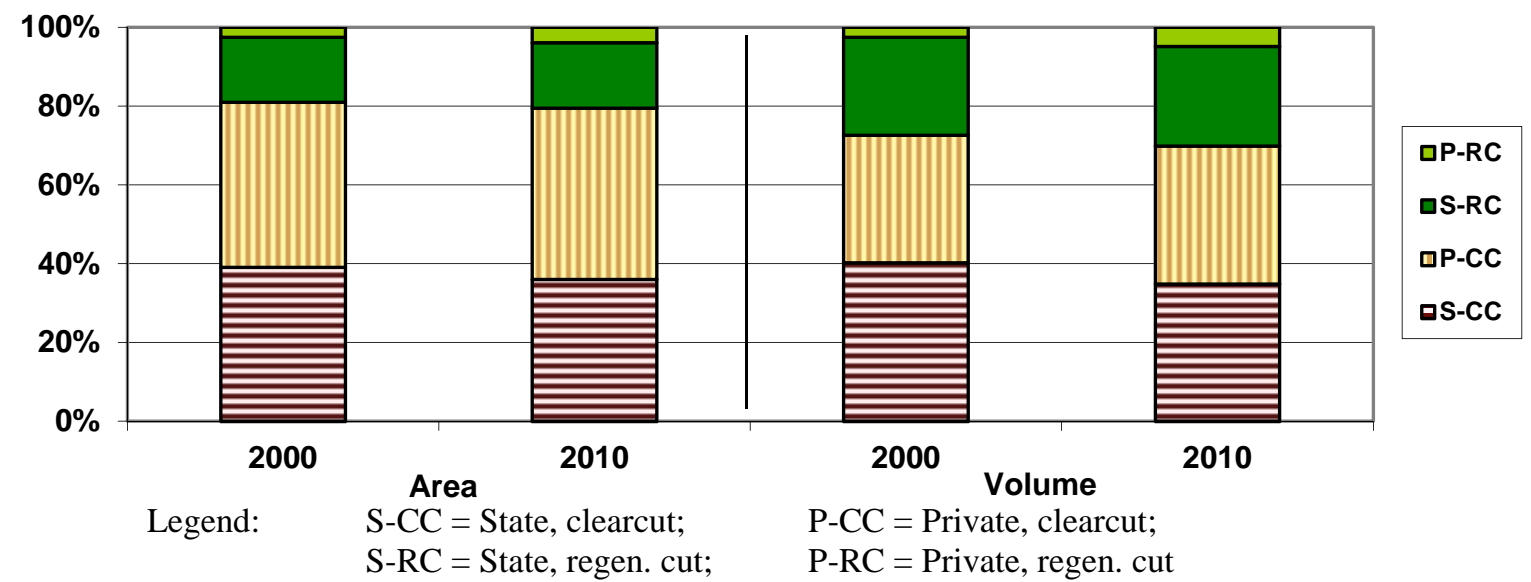

Figure 1: Distribution of final cuts by modes and sectors 2000-2010 (Source of data MgSzH)

\subsection{Volume of final cutting by species and sectors}

In 2000 the statistics of final cuts by species provided the volumes as total, not divided by clearcuts and regeneration cuts, so the table was completely different. The data in Table 4 show the differences between the sectors by species.

Table 4. Volume of final cuts by species and sectors 2010

\begin{tabular}{|c|c|c|c|c|c|c|c|c|}
\hline \multirow{2}{*}{$\begin{array}{l}\text { Species } \\
\text { Total } \\
\end{array}$} & \multicolumn{2}{|c|}{ Clearcut } & \multicolumn{2}{|c|}{ Regen. cut } & \multicolumn{2}{|c|}{ Shelterw. cut } & \multicolumn{2}{|c|}{ Total final cut } \\
\hline & $\left(10^{3} \mathrm{~m}^{3}\right)$ & $(\%)$ & $\left(10^{3} \mathrm{~m}^{3}\right)$ & $(\%)$ & $\left(10^{3} \mathrm{~m}^{3}\right)$ & $(\%)$ & $\left(10^{3} \mathrm{~m}^{3}\right)$ & $(\%)$ \\
\hline 1 Beech & 22.4 & 0.4 & 428.6 & 8.3 & 49.4 & 1.0 & 500.3 & 14.7 \\
\hline Oak & 344.7 & 5.9 & 392.2 & 6.7 & 23.0 & 0.4 & 760.0 & 13.3 \\
\hline Turkey oak & 209.2 & 3.6 & 463.6 & 7.9 & 14.6 & 0.3 & 687.4 & 3.0 \\
\hline Hornbeam & 71.5 & 1.2 & 78.6 & 1.3 & 6.9 & 0.1 & 157.0 & 2.4 \\
\hline Other hardwoods & 101.2 & 1.7 & 20.5 & 0.4 & 4.4 & - & 126.2 & 43.0 \\
\hline 6 LRHW $(1+2+3+4+5$ & 749.0 & 14.4 & $1,353.5$ & 26.1 & 98.3 & 1.9 & $2,230.9$ & 25.6 \\
\hline 7 Black locust & $1,317.4$ & 22.6 & 6.3 & 0.1 & 1.3 & - & $1,325.0$ & 15.5 \\
\hline 8 Hybrid poplar & 805.8 & 13.8 & 0 & - & - & - & 805.9 & 41.1 \\
\hline 9 Black l.+ hyb.popl. & $2,123.2$ & 41.0 & 6.3 & 0.1 & 1.3 & - & $2,130.9$ & 2.4 \\
\hline 10 Poplar & 124.8 & 2.1 & 2.0 & 0 & 0.2 & - & 127.0 & 0.6 \\
\hline 11 Willow & 31.6 & 0.5 & - & - & - & - & 31.6 & 2.8 \\
\hline 12 Other softwood & 123.4 & 2.1 & 20.3 & 0.3 & 2.4 & 0.1 & 146.1 & 10.0 \\
\hline 13 Conifers & 477.2 & 8.2 & 34.9 & 0.6 & 5.6 & 0.1 & 517.7 & 15.9 \\
\hline $\begin{array}{l}14 \text { Other sw and con. } \\
(10+11+12+13)\end{array}$ & 757.0 & 14.6 & 57.2 & 1.1 & 8.2 & 0.2 & 822.4 & 57.0 \\
\hline 15 Non LRHW (9+14) & $2,880.2$ & 55.6 & 63.5 & 1.2 & 9.5 & 0.2 & $2,953.3$ & 14.7 \\
\hline Total $\quad\left(10^{3} \mathrm{~m}^{3}\right)$ & $3,629.2$ & & $1,447.0$ & & 107.9 & & $5,184.1$ & \\
\hline (\%) & & 70.0 & & 27.9 & & 2.1 & & 100 \\
\hline
\end{tabular}


Table 4 continued. Volume of final cuttings by species 2010

\begin{tabular}{|c|c|c|c|c|c|c|c|c|}
\hline \multirow{2}{*}{$\begin{array}{l}\text { Species } \\
\text { State } \\
\end{array}$} & \multicolumn{2}{|c|}{ Clearcut } & \multicolumn{2}{|c|}{ Regen. cut } & \multicolumn{2}{|c|}{ Shelterw. cut } & \multicolumn{2}{|c|}{ Total final cut } \\
\hline & $\left(10^{3} \mathrm{~m}^{3}\right)$ & $(\%)$ & $\left(10^{3} \mathrm{~m}^{3}\right)$ & $(\%)$ & $\left(10^{3} \mathrm{~m}^{3}\right)$ & $(\%)$ & $\left(10^{3} \mathrm{~m}^{3}\right)$ & $(\%)$ \\
\hline 1 Beech & 16.1 & 0.5 & 368.6 & 11.9 & 47.1 & 1.5 & 431.8 & 13.9 \\
\hline 2 Oak & 274.4 & 8.8 & 336.3 & 10.8 & 20.5 & 0.7 & 631.3 & 20.3 \\
\hline 3 Turkey oak & 164.8 & 5.3 & 378.5 & 12.2 & 13.3 & 0.4 & 556.6 & 17.9 \\
\hline 4 Hornbeam & 46.8 & 1.5 & 57.2 & 1.8 & 5.2 & 0.2 & 109.2 & 3.5 \\
\hline 5 Other hardwoods & 68.0 & 2.2 & 17.2 & 0.6 & 4.0 & 0.1 & 89.2 & 2.9 \\
\hline 6 LRHW $(1+2+3+4+5)$ & $\begin{array}{l}570 . \\
31.4\end{array}$ & 18.4 & $\begin{array}{r}1,157.8 \\
63.7\end{array}$ & 37.3 & $\begin{array}{r}90.1 \\
4.9\end{array}$ & 2.9 & $\begin{array}{c}1,818.1 \\
100\end{array}$ & 58.5 \\
\hline 7 Black locust & 410.8 & 13.2 & 2.0 & 0.1 & 0.3 & - & 413.1 & 13.3 \\
\hline 8 Hybrid poplar & 323.5 & 10.4 & - & - & - & - & 323.5 & 10.4 \\
\hline 9 Black l.+ hyb.popl. & 734.3 & 23.6 & 2.0 & 0.1 & 0.3 & & 736.6 & 23.7 \\
\hline 10 Poplar & 67.8 & 2.2 & 1.8 & 0.0 & 0.2 & 0.0 & 69.8 & 2.2 \\
\hline 11 Willow & 18.5 & 0.6 & - & - & - & - & 18.5 & 0.6 \\
\hline 12 Other softwood & 42.3 & 1.4 & 19.7 & 0.6 & 2.4 & 0.1 & 64.4 & 2.1 \\
\hline 13 Conifers & 368.3 & 12.4 & 28.5 & 0.9 & 2.4 & 0.1 & 399.1 & 12.8 \\
\hline 14 Other sw and con. & 496.9 & 16.0 & 50.0 & 1.5 & 5.0 & 0.2 & 551.8 & 17.8 \\
\hline $\begin{array}{r}15 \text { Non LRHW }(9+14) \\
(\%)\end{array}$ & $\begin{array}{r}1,231.2 \\
95.6\end{array}$ & 39.6 & $\begin{array}{r}52.0 \\
4.0\end{array}$ & 1.6 & $\begin{array}{l}5.3 \\
0.4\end{array}$ & 0.2 & $\begin{array}{c}1,288.4 \\
100\end{array}$ & 41.5 \\
\hline $\begin{array}{rrr}\text { Total } & \left(10^{3} \mathrm{~m}^{3}\right) & \mathbf{1} \\
& (\%) \\
\end{array}$ & $1,801.3$ & 58.0 & $1,209.8$ & 38.9 & 95.4 & .1 & $\begin{array}{c}3,106.5 \\
100\end{array}$ & 100 \\
\hline Private & & & & & & & & \\
\hline 1 Beech & 6.3 & 0.3 & 59.9 & 2.7 & 2.3 & 0.1 & 68.5 & 3.3 \\
\hline 2 Oak & 70.3 & 3.2 & 55.7 & 2.5 & 2.4 & 0.1 & 128.4 & 6.2 \\
\hline 3 Turkey oak & 43.4 & 2.0 & 85.0 & 3.9 & 1.2 & 0.1 & 129.6 & 6.3 \\
\hline 4 Hornbeam & 24.6 & 1.1 & 21.4 & 1.0 & 1.5 & 0.1 & 47.5 & 2.3 \\
\hline 5 Other hardwoods & 33.1 & 1.5 & 3.3 & 0.2 & 0.2 & - & 36.6 & 1.8 \\
\hline 6 LRHW $(1+2+3+4+5)$ & $\begin{array}{r}177.7 \\
43.3\end{array}$ & 8.6 & $\begin{array}{r}225.3 \\
54.9\end{array}$ & 10.9 & $\begin{array}{l}7.6 \\
1.8\end{array}$ & 0.4 & $\begin{array}{l}410.6 \\
100\end{array}$ & 19.9 \\
\hline 7 Black locust & 901.3 & 43.7 & 4.3 & 10.1 & 0.9 & - & 906.5 & 44.0 \\
\hline 8 Hybrid poplar & 477.6 & 23.1 & - & - & - & - & 477.6 & 23.1 \\
\hline 9 Black l.+ hyb.popl. 1 & $1,378.9$ & 66.9 & 4.3 & 10.1 & 0.9 & - & $1,384.1$ & 67.1 \\
\hline 10 Poplar & 56.6 & 2.6 & 0.3 & - & - & - & 56.9 & 2.8 \\
\hline 11 Willow & 12.9 & 0.6 & - & - & - & - & 12.9 & 0.6 \\
\hline 12 Other softwood & 80.2 & 3.7 & 0.6 & - & 0.1 & - & 80.8 & 3.9 \\
\hline 13 Conifers & 107.0 & 6.9 & 6.5 & 0.3 & 3.2 & 0.1 & 116.7 & 5.7 \\
\hline 14 Other sw and con. & 256.7 & 12.4 & 7.4 & 0.3 & 3.3 & 0.1 & 267.3 & 13.0 \\
\hline $\begin{array}{r}15 \text { Non LRHW }(9+14) \\
(\%)\end{array}$ & $\begin{array}{r}1,635.6 \\
99.0\end{array}$ & 79.3 & $\begin{array}{r}11.7 \\
0.7\end{array}$ & 0.6 & $\begin{array}{l}4.2 \\
0.3\end{array}$ & 0.2 & $\begin{array}{c}1,651.4 \\
100\end{array}$ & 80.1 \\
\hline $\begin{array}{rr}\text { Total } & \left(10^{3} \mathrm{~m}^{3}\right) \\
(\%) & 1 \\
\end{array}$ & $1,813.4$ & 87.9 & 236.9 & 11.5 & 11.7 & 0.6 & $\begin{array}{c}2,062.0 \\
100\end{array}$ & \\
\hline
\end{tabular}

Legend: LRHW= long rotation hardwood

Source of data MgSzH

The proportion of clear cut in state and private forests are nearly similar in area and volume, but the species distribution and, therefore, the management conditions are substantially different. In private forestry, the role of black locust is vast and the role of hybrid poplars is also important. 
The majority of final cuttings in state forestry consist of broadleaved hardwood stands $(58.5 \%)$. In these stands clearcut does not reach one third of the area (in the case of beech not even $5 \%$ ), while in other species this proportion is $95 \%$.

In private forestry the share of broadleaved hardwoods is only one fifth, and black locust (44\%) and hybrid poplar (23\%) are in majority. With other species clearcut is nearly $99 \%$, while in the case of broadleaved hardwoods the situation is similar to that in state forests.

Using clearcut or regeneration cut depends mainly on species, but other factors and stand characteristics can also influence the decision.

Behind the differences in final cutting - regeneration modes between sectors (Figure 2) are the differences in species, so the differentiation is for the long run. In the species composition of regeneration cuts, the difference is much smaller (beech is important in state forests) and in clearcut, oak is important in state forests.

\section{Volume}

Thousand $\mathrm{m}^{3}$

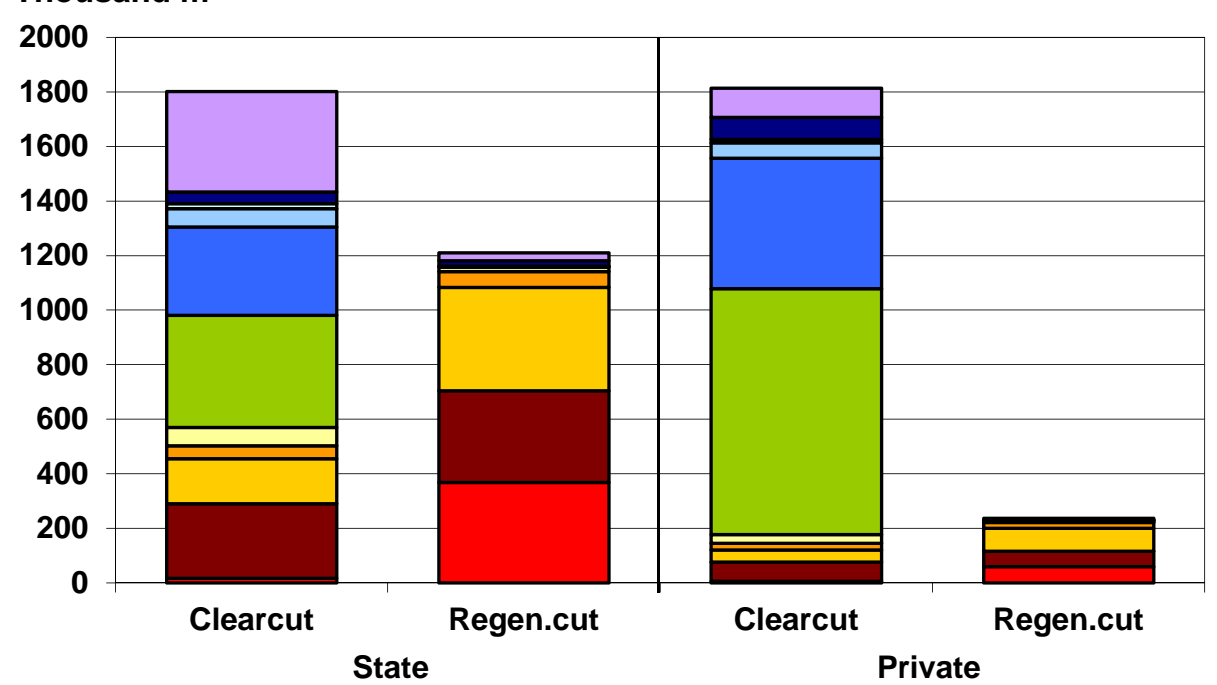

口Conifers

-Other SW

口Willow

口Poplar

口Hybrid poplar

口Black locust

口Other HW

口Hornbeam

口Turkey oak

口Oak

$\square$ Beech

Volume \%
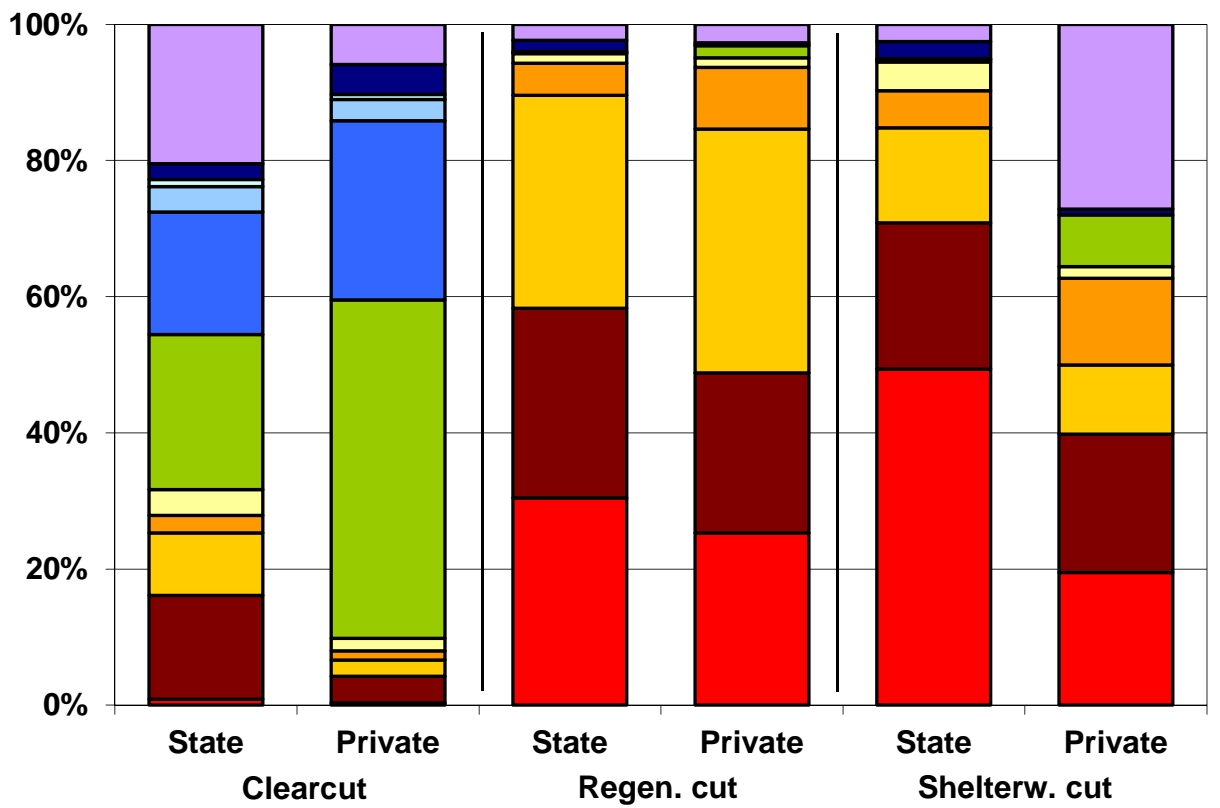

口Conifers

-Other SW

口Willow

口Poplar

口Hybrid poplar

口Black locust

口Other HW

口Hornbeam

口Turkey oak

-Oak

口Beech

Figure 2. Comparison of state and private forest resource management (Source of data $\mathrm{MgSzH}$ ) 
Based on the data in Table 4 and Figure 3, the following statements can be made:

- proportion of regeneration cuts in turkey oak is higher than in oak (similarly to beech) in both sectors

- regeneration cuts are negligible in short rotation stands and no increase is expected

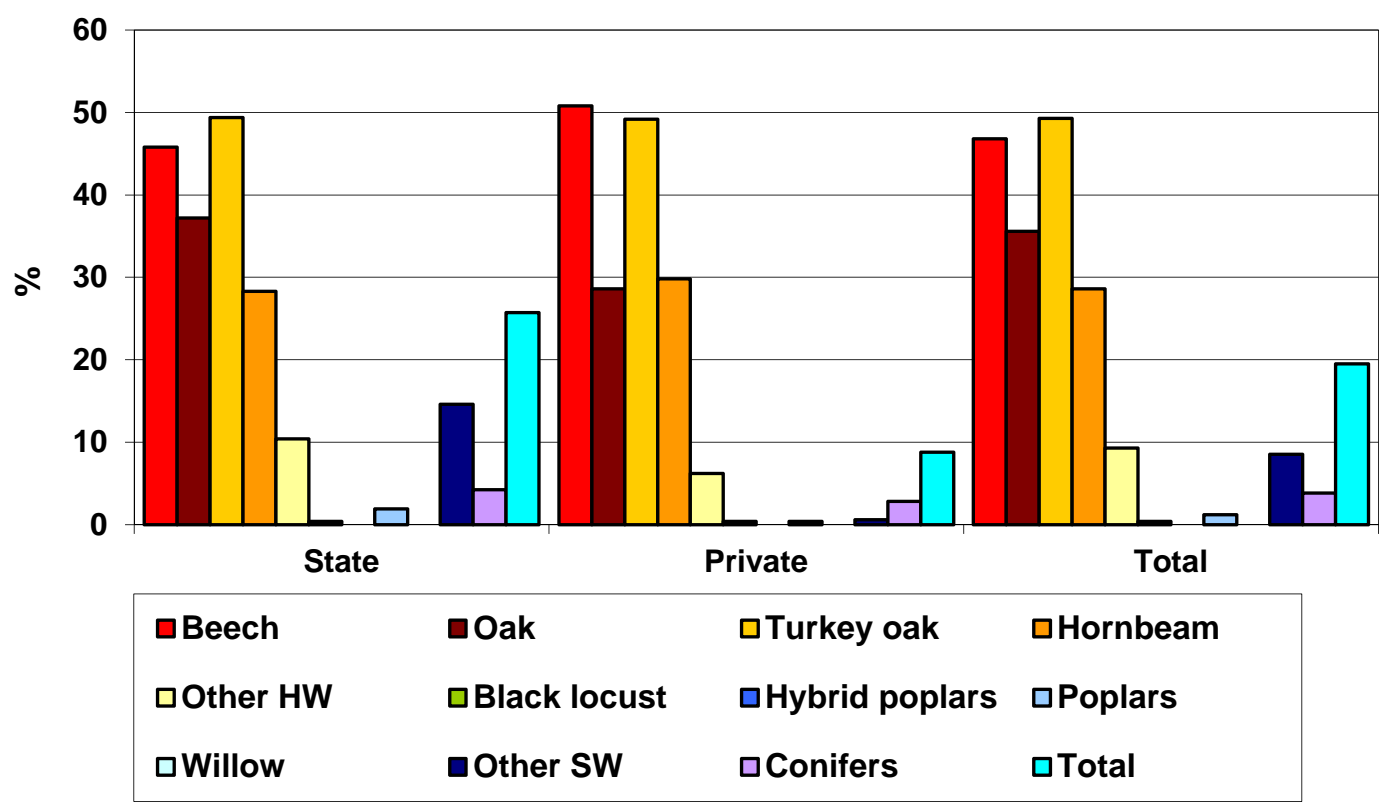

Figure 3: Proportions of regeneration cuts (2010) (Source of data MgSzH)

Annual final cuttings have stabilized, the changes do not have a tendency, the increase of conifers is steady, and a decrease is expected with hybrid poplars (Figure 4)

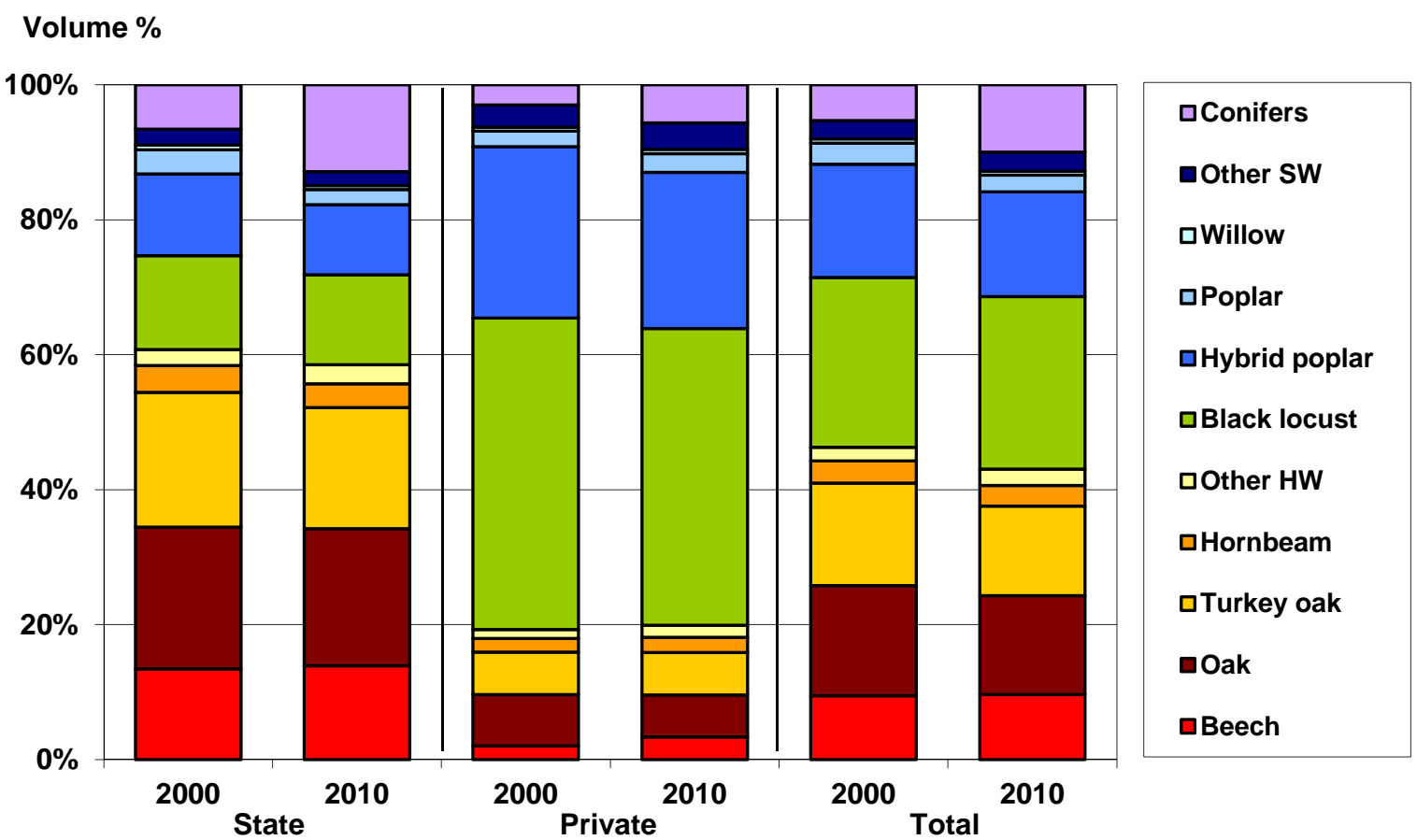

Figure 4. Change of final cutting by species (2000-2010) (Source of data MgSzH) 
According to proportion of final cut, species groups with good separation can be observed (Table 5) and rotation age is an important influencing factor:

- below $55 \%$, conifers because of the age structure

- between 55-70\%, native stands with high rotation age (but also other softwood in the state forest category)

- final cut proportion is over $70 \%$ in the case of short rotation age

- with some species the final cut proportion is lower in the state forest than in private forest, the rotation age is higher,

- there is no substantial change in time because of the stable species structure, only slow change is to be expected,

- the final cut proportion is two-thirds in the state forest, and about three-quarters in the private forest

Table 5. Proportion of final cut volume within total timber removal in 2000 and in 2010 (\%)

\begin{tabular}{lllllll}
\hline \multirow{2}{*}{ Species } & \multicolumn{2}{c}{ State } & \multicolumn{2}{c}{ Private } & \multicolumn{2}{c}{ Total } \\
& 2000 & 2010 & 2000 & 2010 & 2000 & 2010 \\
\hline Beech & 70.1 & 53.7 & 62.1 & 58.1 & 69.4 & 54.6 \\
Oak & 69.7 & 69.7 & 67.5 & 65.9 & 69.3 & 69.0 \\
Turkey oak & 76.0 & 72.7 & 57.8 & 75.1 & 75.9 & 73.2 \\
Hornbeam & 47.3 & 54.0 & 56.8 & 66.2 & 49.1 & 57.2 \\
Other HW & 53.8 & 54.2 & 66.3 & 68.5 & 56.3 & 57.5 \\
\hline Black locust & 79.9 & 78.3 & 87.1 & 82.9 & 84.4 & 81.4 \\
Hybrid poplar & 78.2 & 81.4 & 79.3 & 82.7 & 78.8 & 82.2 \\
Poplar & 60.4 & 73.9 & 71.1 & 75.7 & 76.6 & 74.1 \\
Willow & 47.1 & 70.3 & 61.1 & 79.6 & 60.7 & 74.2 \\
Other SW & 51.5 & 47.6 & 68.8 & 78.1 & 57.7 & 60.9 \\
Conifers & 33.6 & 58.7 & 26.2 & 51.2 & 31.8 & 56.9 \\
\hline Total & 66.1 & 66.1 & 74.7 & 76.4 & 68.9 & 69.8 \\
\hline
\end{tabular}

\section{PERFORMANCE AND CHANGE OF COMPOSITION OF REFORESTATION}

\subsection{Mode and performance of reforestation (2000-2009)}

The forest resource management of the 2000's was determined by financing along similar principles, but with different practices: funds for supporting forest resource and normative financing of regeneration. The effects if its termination in 2008 will be detectable only after several years have passed.

The proportion of regeneration cut has not reached one-fifth in the state-owned forests, and within this artificial regeneration there is more regeneration than natural seed origin in clearcuts. In private forestry, natural regeneration can be applied only to some species, but black locust coppice regeneration reduces artificial regeneration, thus reducing costs for the forest manager (Table 6, Figure 5).

In the forest resource management of the state-owned forest, use of regeneration cut has exceeded one-quarter (we will get back to this when species distribution is discussed). There is still more artificial regeneration in regeneration cuts (with its high costs) than seed origin in clearcuts. 
The first plantings in 2000 and the completed reforestations in 2008/2009 can be compared; regeneration cuts slightly decreased, artificial regenerations and coppice regenerations increased at the expense of natural seed regeneration.

In the vegetation year 2008/2009, there is no considerable change in the area and proportions of regeneration cuts, perhaps the natural seed regeneration increased in private forestry.

Table 6. Regeneration - First planting (2009) (ha)

\begin{tabular}{lrrrrrrrrrr}
\hline $\begin{array}{l}\text { Mode of } \\
\text { regeneration }\end{array}$ & \multicolumn{3}{c}{$\begin{array}{c}\text { State } \\
\text { RC }\end{array}$} & \multicolumn{1}{c}{ Total } & \multicolumn{1}{c}{ CC } & \multicolumn{1}{c}{ RC } & Total & \multicolumn{1}{c}{ CC } & \multicolumn{1}{c}{ RC } & Total \\
\hline Natural seed & 63 & 2,920 & 2,984 & 95 & 726 & 821 & 158 & 3,646 & 3,804 \\
Natural Coppice & 2,027 & - & 2,027 & 4,309 & - & 4,308 & 6,336 & - & 6,336 \\
Artificial & 4,916 & 83 & 4,999 & 3,624 & 7 & 3,631 & 8,540 & 90 & 8,630 \\
\hline Total & $\mathbf{7 , 0 0 7}$ & $\mathbf{3 , 0 0 3}$ & $\mathbf{1 0 , 0 1 0}$ & $\mathbf{8 , 0 2 8}$ & $\mathbf{7 3 3}$ & $\mathbf{8 , 7 6 1}$ & $\mathbf{1 5 , 0 3 4}$ & $\mathbf{3 , 7 3 6}$ & $\mathbf{1 8 , 7 7 0}$ \\
\hline Additional plant. & 1,939 & 918 & 2,857 & 677 & 45 & 722 & 2,630 & 964 & 3,594 \\
\hline
\end{tabular}

Legend: $\quad \mathrm{CC}=$ clearcut; $\mathrm{RC}=$ regeneration cut;

Source of data $\mathrm{MgSzH}$

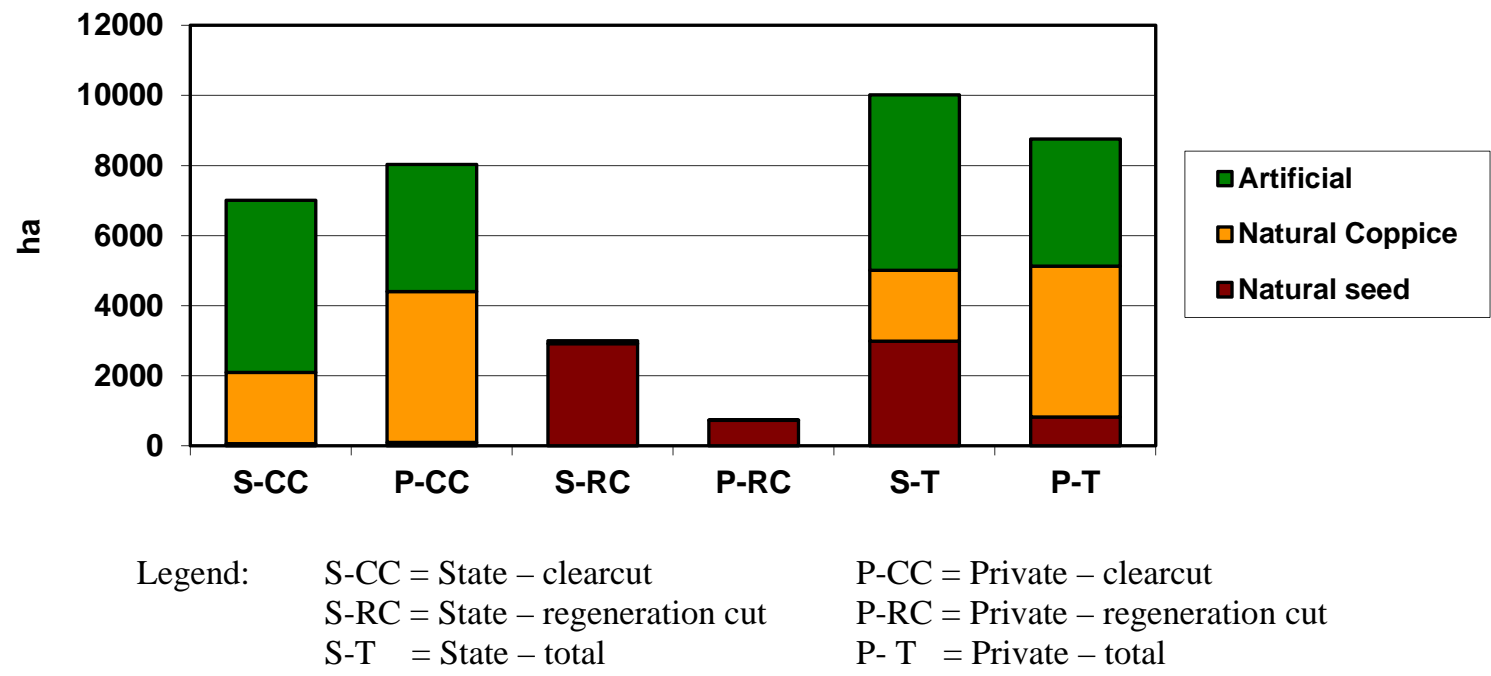

Figure 5. Final cuttings - reforestation first planting by sector (2009)

Annual replacements of plants are attached to the first plantings, though there are no data available on the distribution of species or on the mode of regeneration.

We will investigate the data of the afforestation for the last year in more detail. The combination of clearcut and natural regeneration from seed hardly occurs, and artificial regeneration and regeneration is also rare (regeneration cut and coppice regeneration does not occur at all). There are considerable differences between state and private management in terms of cutting and regeneration modes:

The proportion of natural regeneration from seeds does not reach $20 \%$ proportion and is mainly concentrated in state forests. One-third of the regenerations are done naturally, but from coppice (the distribution of the coppice regenerations by age and species needs a separate investigation because of the still existing old stands).

Nearly half of the regenerations are artificial regeneration after clearcut.

There is a considerable difference between sectors in regeneration after clearcut. In the case of state forests, two-thirds are regenerated artificially, while in private forests the proportion of natural coppice is higher. In the case of regeneration cuts, natural seed regeneration is dominant. 


\subsection{Comparison of regenerations by species and sector}

The previous chapter presented the relation of utilization and regeneration and the differences in sectors. These sectorial differences can be explained by the difference of species of regeneration. Clearcut is dominant in private forestry (and within this, mainly black locust and less hybrid poplar) and regeneration cut is marginal. On the species level, there is little difference between sectors in the utilization and regeneration modes. (Table 7 and Figure 6)

Table 7. Regeneration and first planting by species (2010) (ha)

\begin{tabular}{lrrrrrr}
\hline \multirow{2}{*}{ Species } & \multicolumn{2}{c}{ Clearcut } & \multicolumn{2}{c}{ Regeneration cut } & \multicolumn{2}{c}{ Total } \\
& State & Private & State & Private & State & Private \\
\hline Beech & 75 & 13 & 945 & 191 & 1,020 & 204 \\
Oak & 1,571 & 660 & 970 & 260 & 2,541 & 920 \\
Turkey oak - other hw. & 755 & 286 & 1,053 & 281 & 1,808 & 567 \\
\hline LRHW & $\mathbf{2 , 4 0 1}$ & $\mathbf{9 5 9}$ & $\mathbf{2 , 9 6 8}$ & $\mathbf{7 3 2}$ & $\mathbf{5 , 3 6 9}$ & $\mathbf{1 , 6 9 1}$ \\
\hline Black locust & 2,065 & 4,748 & - & - & 2,065 & 4,748 \\
Hybrid poplar & 681 & 1,306 & 1 & - & 682 & 1,306 \\
Other softwood & 1,231 & 889 & & - & 1,232 & 889 \\
Conifers & 629 & 127 & 34 & 1 & 663 & 128 \\
\hline Non LRHW & $\mathbf{4 , 6 0 6}$ & $\mathbf{7 , 0 7 0}$ & $\mathbf{3 5}$ & $\mathbf{1}$ & $\mathbf{4 , 6 4 1}$ & $\mathbf{7 , 0 7 1}$ \\
\hline Total & $\mathbf{7 , 0 0 7}$ & $\mathbf{8 , 0 2 9}$ & $\mathbf{3 , 0 0 3}$ & $\mathbf{7 3 3}$ & $\mathbf{1 0 , 0 1 0}$ & $\mathbf{8 , 7 6 2}$ \\
\hline
\end{tabular}

Legend: LRHW= long rotation hardwood Source of data $\mathrm{MgSzH}$

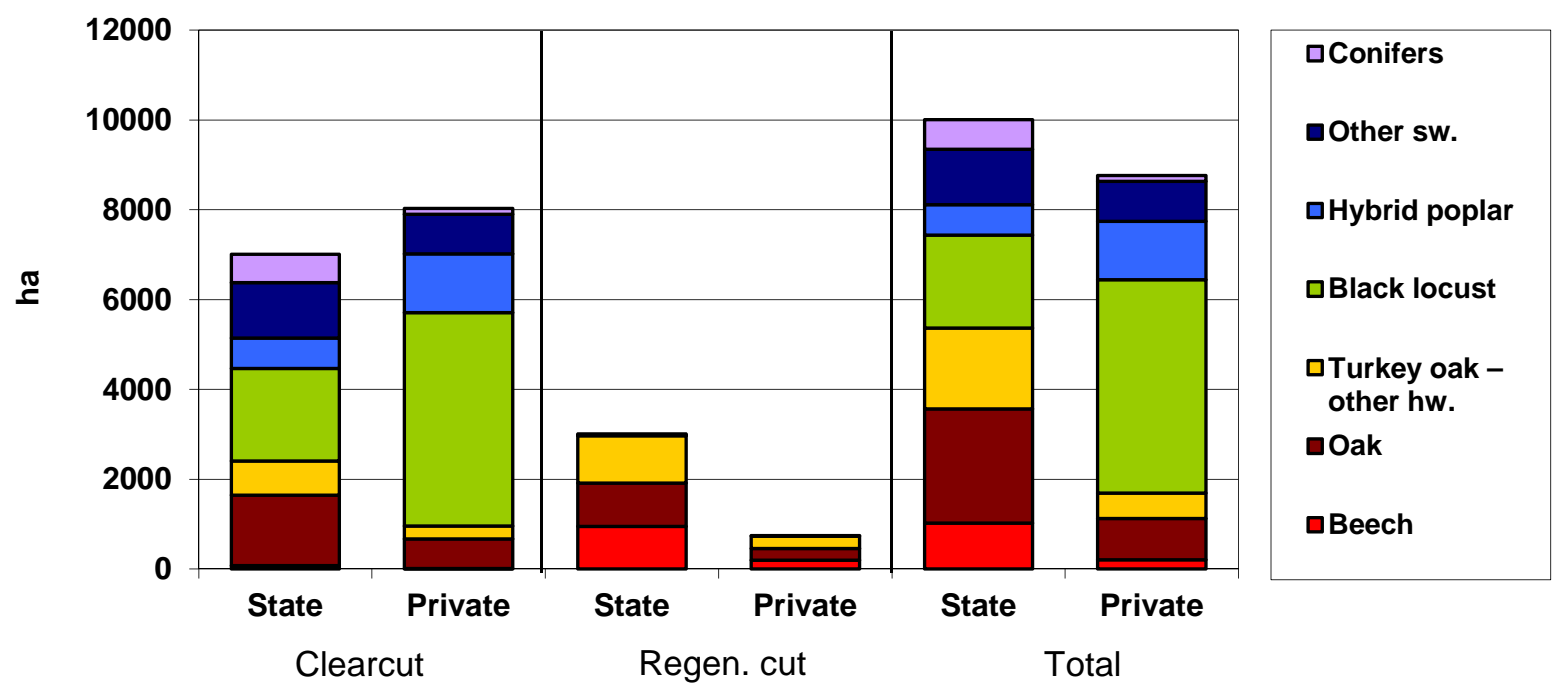

Figure 6. First planting of regenerations by species (2010) (Source of data MgSzH)

\subsection{Change of regeneration modes and performance}

Taking into consideration the two dates of finished regenerations and first plantings (2000, 2010), four series of data can be used to investigate an approximate time period of fifteen years. The distribution of regeneration cut - clearcut comes from final cuttings, and to these three regeneration modes can be assigned: natural regeneration from seeds, and coppice, and artificial regeneration. The distribution of cutting modes (clearcut and regeneration cut) and regeneration modes (natural seed, natural coppice, artificial) by sectors is presented in Table 8 and Figure 7. The species composition and its change show the difference between management in the sectors. 
Table 8. Change regeneration mode and performance

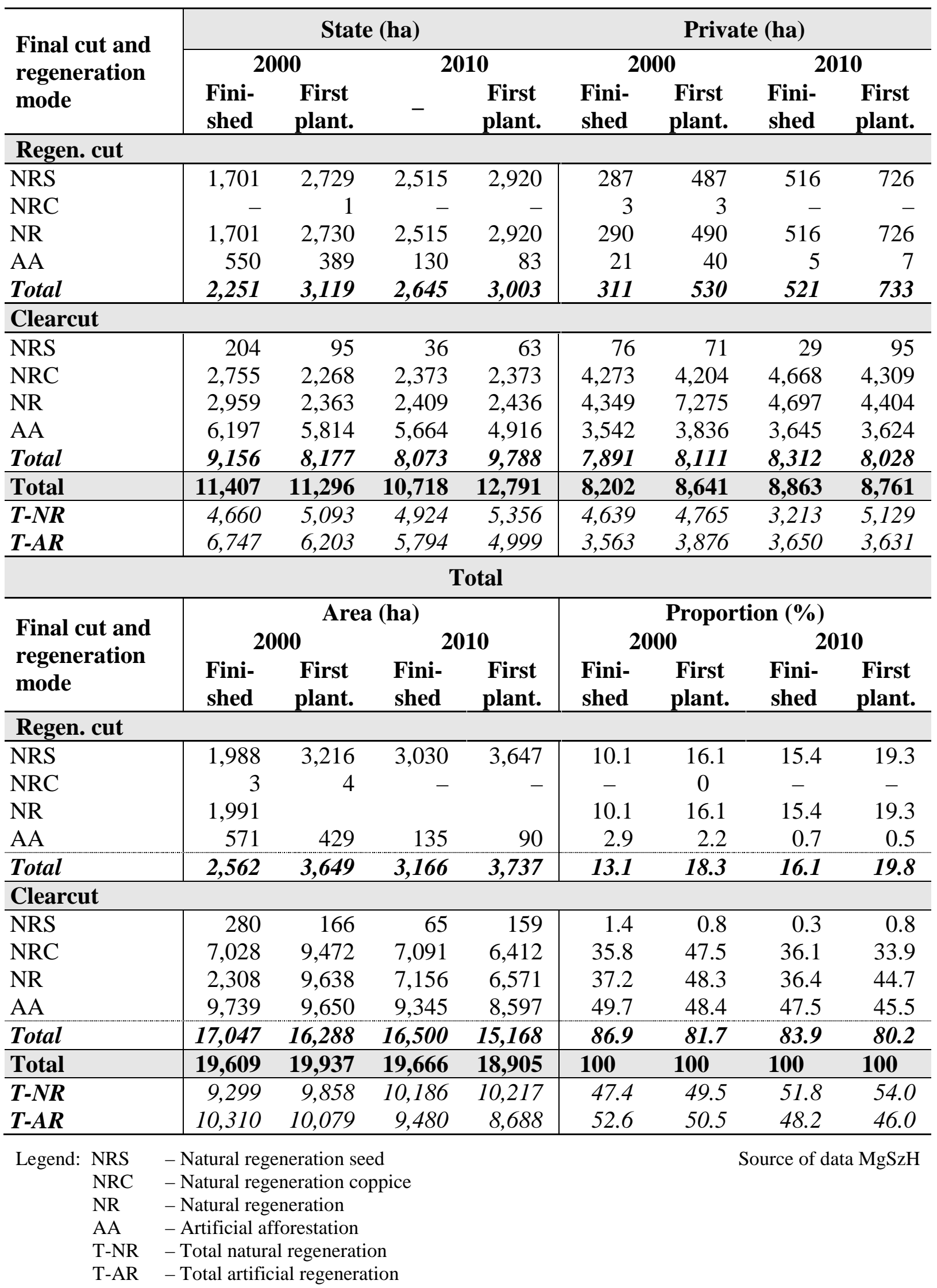



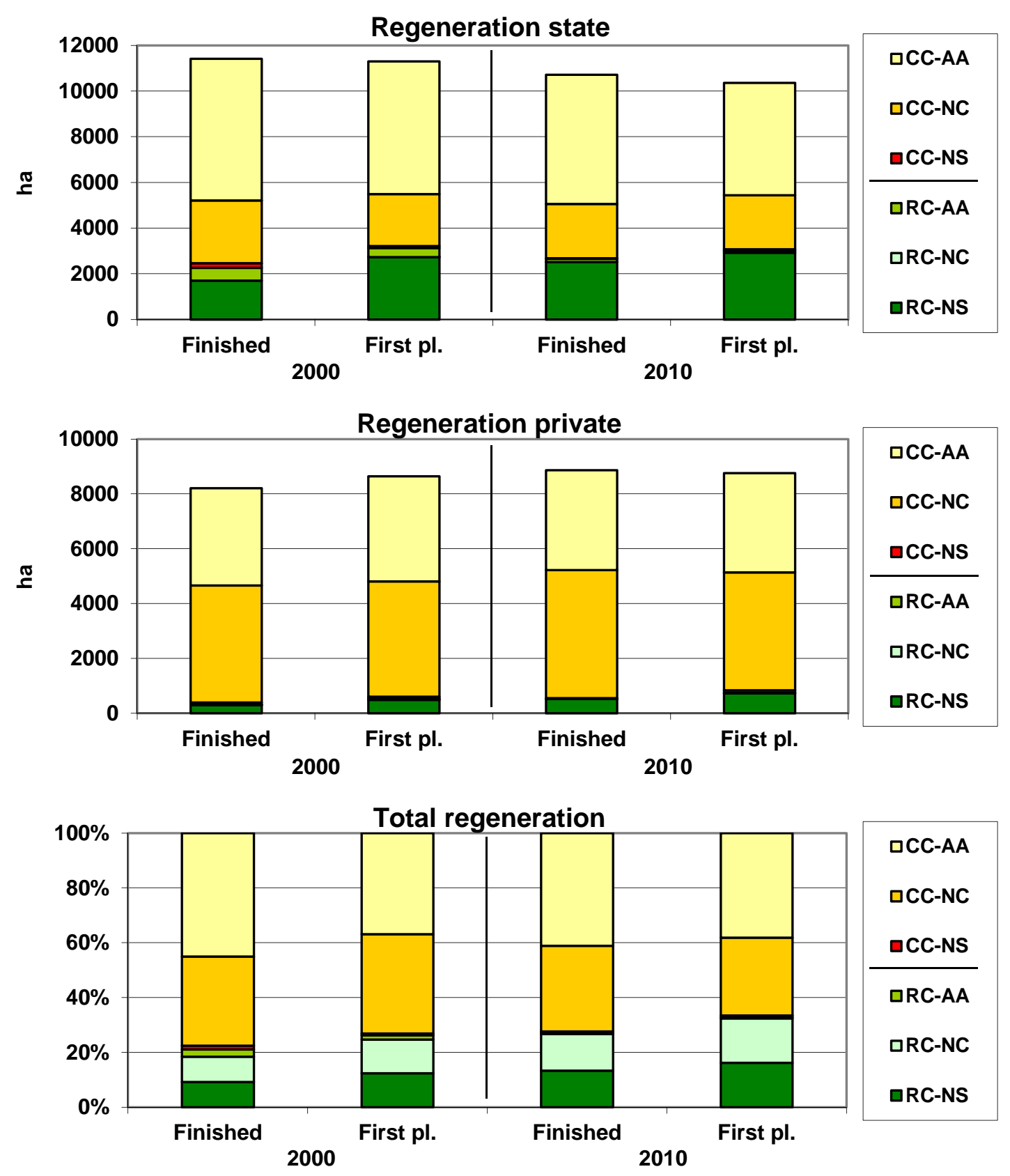

$\mathrm{CC}=$ Clearcut $\mathrm{RC}=$ Regeneration cut

$\mathrm{NS}=$ Natural seed $; \mathrm{NC}=$ Natural coppice; $\mathrm{AA}=$ artificial afforestation

Figure 7. Change of mode and performance of regeneration in state and private sector (Source of data $\mathrm{MgSzH}$ )

\subsection{Change of species composition in regeneration}

The difference between modes of cut and regeneration method combinations is primarily defined by the species conditions (and site differences determining these conditions, Table 9, Figure 8).

With the species black locust, poplar, and conifers clearcut is dominant as the final cutting mode, and as regeneration, natural coppice is typical for black locust; otherwise, artificial regeneration with plants is usual. Different proportions of regeneration cuts (natural regeneration with seeds) by species can be mentioned with broadleaved hardwoods with a long rotation age, where the difference between sectors is smaller and the change is more evident in the first plantings (thus appearing in planning). 
Table 9. Change in species structure of regeneration

\begin{tabular}{|c|c|c|c|c|c|c|c|c|}
\hline \multirow{3}{*}{ Species } & \multicolumn{4}{|c|}{ State (ha) } & \multicolumn{4}{|c|}{ Private (ha) } \\
\hline & \multicolumn{2}{|c|}{2000} & \multicolumn{2}{|c|}{2010} & \multicolumn{2}{|c|}{2000} & \multicolumn{2}{|c|}{2010} \\
\hline & $\begin{array}{l}\text { Fini- } \\
\text { shed }\end{array}$ & $\begin{array}{l}\text { First } \\
\text { plant. }\end{array}$ & $\begin{array}{l}\text { Fini- } \\
\text { shed }\end{array}$ & $\begin{array}{l}\text { First } \\
\text { plant. }\end{array}$ & $\begin{array}{l}\text { Fini- } \\
\text { shed }\end{array}$ & $\begin{array}{l}\text { First } \\
\text { plant. }\end{array}$ & $\begin{array}{l}\text { Fini- } \\
\text { shed }\end{array}$ & $\begin{array}{l}\text { First } \\
\text { plant. }\end{array}$ \\
\hline \multicolumn{9}{|l|}{ Regen. cut } \\
\hline Beech & 628 & 955 & 642 & 945 & 60 & 84 & 110 & 191 \\
\hline Oak & 714 & 995 & 797 & 970 & 77 & 169 & 145 & 260 \\
\hline Turkey oak - OHW & 897 & 1,156 & 1,199 & 1,053 & 163 & 270 & 262 & 281 \\
\hline LRHW & 2,239 & 3,106 & 2,638 & 2,968 & 300 & 523 & 517 & 732 \\
\hline Total & 2,251 & 3,119 & 2,645 & 3,003 & 311 & 530 & 521 & 778 \\
\hline \multicolumn{9}{|l|}{ Clearcut } \\
\hline Beech & 120 & 109 & 56 & 75 & 14 & 21 & 10 & 13 \\
\hline Oak & 1,736 & 1,841 & 1,919 & 1,571 & 381 & 643 & 677 & 660 \\
\hline Turkey oak - OHW & 1,104 & 937 & 811 & 754 & 349 & 293 & 303 & 286 \\
\hline LRHW & 2,960 & 2,877 & 2,786 & 2,400 & 744 & 957 & 990 & 959 \\
\hline Black locust & 3,156 & 2,706 & 2,589 & 2,065 & 4,600 & 4,495 & 5,241 & 4,748 \\
\hline Hybrid poplar & 1,312 & 1,099 & 973 & 681 & 1,674 & 1,851 & 1,320 & 1,306 \\
\hline Poplar & 759 & 924 & 1,224 & 1,231 & 545 & 634 & 666 & 889 \\
\hline Conifers & 927 & 564 & 502 & 628 & 268 & 156 & 123 & 127 \\
\hline Total & 9,156 & 8,177 & 8,073 & 7,007 & 7,891 & 8,111 & 8,342 & 8,705 \\
\hline Total & 11,407 & 11,296 & 10,718 & 10,010 & 8,202 & 8,641 & 8,863 & 9,483 \\
\hline \multicolumn{9}{|c|}{ Total } \\
\hline \multirow{3}{*}{ Species } & \multicolumn{4}{|c|}{ Area (ha) } & \multicolumn{4}{|c|}{ Proportion (\%) } \\
\hline & \multicolumn{2}{|c|}{2000} & \multicolumn{2}{|c|}{2010} & \multicolumn{2}{|c|}{2000} & \multicolumn{2}{|c|}{2010} \\
\hline & $\begin{array}{l}\text { Fini- } \\
\text { shed }\end{array}$ & $\begin{array}{c}\text { First } \\
\text { plant. }\end{array}$ & $\begin{array}{l}\text { Fini- } \\
\text { shed }\end{array}$ & $\begin{array}{c}\text { First } \\
\text { plant. }\end{array}$ & $\begin{array}{l}\text { Fini- } \\
\text { shed }\end{array}$ & $\begin{array}{l}\text { First } \\
\text { plant. }\end{array}$ & $\begin{array}{l}\text { Fini- } \\
\text { shed }\end{array}$ & $\begin{array}{l}\text { First } \\
\text { plant. }\end{array}$ \\
\hline \multicolumn{9}{|l|}{ Regen. cut } \\
\hline Beech & 688 & 1,039 & 753 & 1,137 & 3.5 & 5.2 & 3.8 & 6.0 \\
\hline Oak & 791 & 1,164 & 942 & 1,231 & 4.0 & 5.8 & 4.8 & 6.5 \\
\hline Turkey oak - OHW & 1,060 & 1,426 & 1,462 & 1,335 & 5.4 & 7.2 & 7.4 & 7.1 \\
\hline HVFK & 2,539 & 3,629 & 3,157 & 3,703 & 12.9 & 18.2 & 16.0 & 19.6 \\
\hline Total & 2,562 & 3,649 & 3,166 & 3,737 & 13.1 & 18.3 & 16.1 & 19.8 \\
\hline \multicolumn{9}{|l|}{ Clearcut } \\
\hline Beech & 134 & 130 & 65 & 88 & 0.7 & 0.7 & 0.3 & 0.5 \\
\hline Oak & 2,117 & 2,484 & 2,596 & 2,243 & 10.8 & 12.5 & 13.2 & 11.9 \\
\hline Turkey oak - OHW & 1,453 & 1,220 & 1,115 & 1,045 & 7.4 & 6.1 & 5.7 & 5.5 \\
\hline LRHW & 3,704 & 3,834 & 3,776 & 3,376 & 18.9 & 19.2 & 18.9 & 17.9 \\
\hline Black locust & 7,756 & 7,201 & 7,883 & 6,901 & 39.6 & 36.1 & 40.1 & 36.5 \\
\hline Hybrid poplar & 2,986 & 2,950 & 2,323 & 2,007 & 15.2 & 14.8 & 11.8 & 10.6 \\
\hline Poplar & 1,304 & 1,558 & 1,891 & 2,127 & 6.7 & 7.8 & 9.6 & 11.3 \\
\hline Conifers & 1,195 & 720 & 626 & 754 & 6.1 & 3. & 3.1 & 4.0 \\
\hline Total & 17,047 & 16,288 & 16,500 & 15,168 & 86.9 & 81.7 & 83.9 & 80.2 \\
\hline Total & 19,609 & 19,937 & 19,666 & 18,905 & 100 & 100 & 100 & 100 \\
\hline Total hardwood & 6,243 & 7,463 & 6,933 & 7,079 & & & & \\
\hline \multicolumn{9}{|c|}{$\begin{array}{ll}\text { Legend: } & \text { OHW }=\text { other hardwoods } \\
& \text { LRHW }=\text { hardwoods with long rotation age }\end{array}$} \\
\hline
\end{tabular}



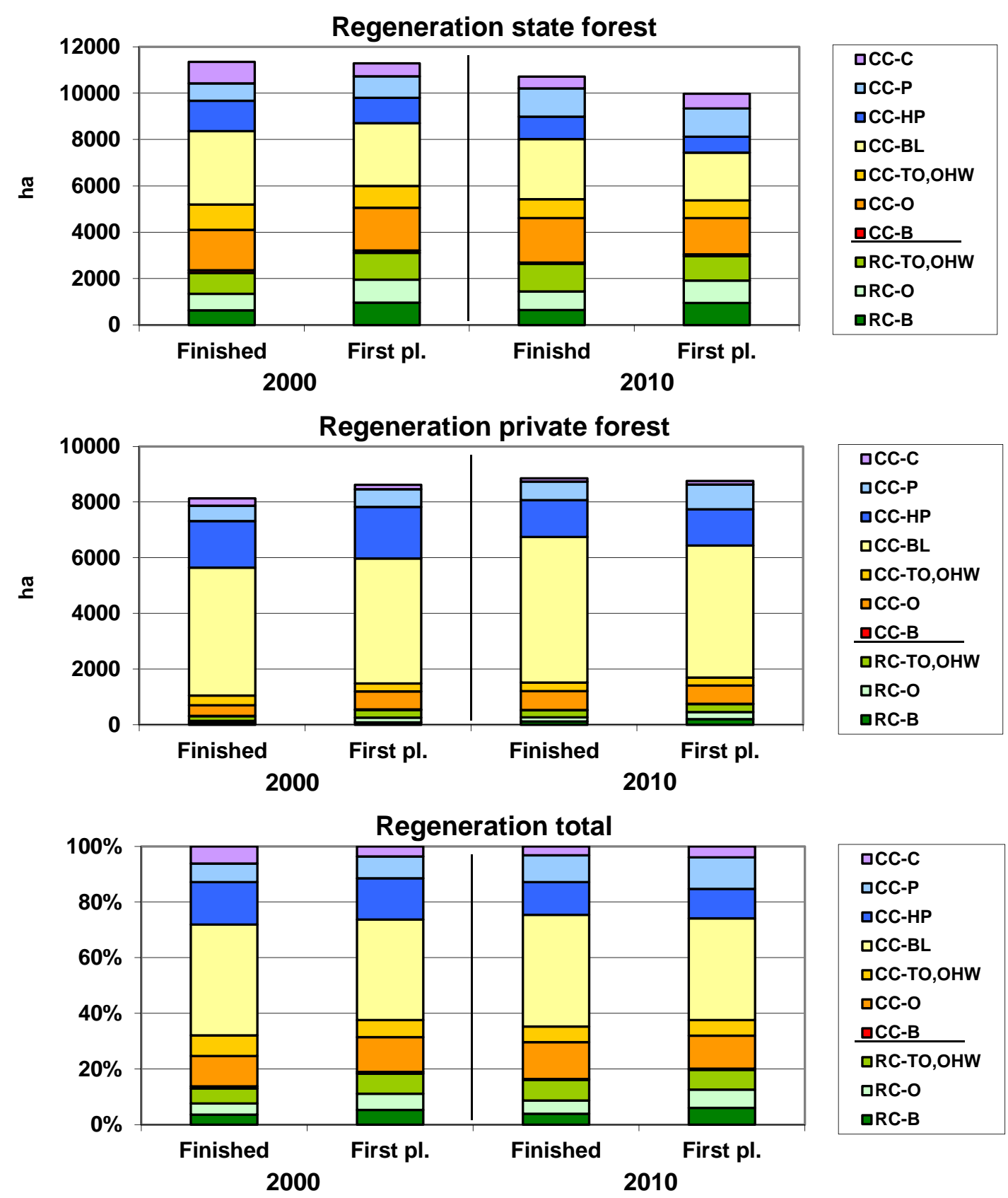

$\mathrm{CC}=$ clearcut; $\mathrm{RC}=$ Regen. cut
$\mathrm{B}=$ beech; $\mathrm{O}=$ oak; $\mathrm{TO}=$ turkey oak; $\mathrm{OHW}=$ other hardwood;
$\mathrm{BL}=$ black locust; HP=Hybrid poplar; $\mathrm{P}=$ poplar; $\mathrm{F}$ C=conifers

Figure 8. Change of species structure in regenerations (Source of data $\mathrm{MgSzH}$ )

\section{SUMMARY}

The modification of forest management regulations changes the practice of forest management fundamentally. The changes in legal regulation, including the ratification of the forest law in 1996, facilitated the increase of protected areas, which was followed by the designation of NATURA 2000 sites by the middle of 2000s. This process was coupled with a considerable social pressure represented by NGOs to widen protection functions of forests and to apply close-to-nature silviculture. As a result, forest management had to face increasing restrictions on forest operations limiting available technology, the time frame of fellings, and also the allowable cut. 
Also, within the forestry community the idea and the new possibilities of close-to-nature methods found supporters. In regions where protection measures prohibited timber harvest completely using clear cut or short period regeneration cuttings, close-to-nature silviculture provided the only way to utilize timber yield. In other cases, forest regeneration with natural regeneration methods resulted in cost reduction.

This process reached another milestone in 2010 , when a completely new forestry law was ratified introducing a classification of forests according to their natural state, a more - but not perfectly - accurate regulation of the selection system and other silvicultural methods, and also measures for the state forests on the application of these redefined methods.

This analysis attempted to describe the above process by quantifying the changes with statistical data on timber harvest and forest regeneration in the period of 2000-2010. Findings of this article reveal that:

- Forest resource management cannot apply universal concepts for the whole country; smaller regions should be designated with regulations suitable for the local specific conditions.

- Changes in the application of new silvicultural methods require long period of time

o Any large-scale changes in silvicultural methods first shall appear in forest management plans, which have a 10 year cycle. Changes in forestry practice can, therefore, be only gradual.

- New or rarely used silvicultural methods are often handicapped by initial skepticism and resistence. Research, field experiments, active dissemination of information, and participatory processes are prerequisites for successful introduction of new methods, all of which is time consuming.

- First signs of changes could be observed in broadleaved hardwood forests with long rotation age, where natural forest regeneration started to increase.

- Beech tends to be suitable for natural regeneration and selection systems, as these methods have the highest share in beech stands.

- Black locust and hybrid poplars are plantations, and close-to-nature silvicultural methods cannot be applied in these stands without losing their goals of production and their profitability.

- Black locust and hybrid poplars have a large share in forest areas, which limits the propagation of close-to-nature silvicultural methods.

- Forest characteristics, especially species distribution in the private and the public (state and community) sector are significantly different, which is reflected in the application of close-to-nature silvicultural methods.

- Within the same species categories, private and public sectors show minor differences. In the case of beech, private forestry shows higher (but still low) level of clearcuts, while in the case of oak and turkey oak, close-to-nature silviculture is more common in the private sector than in the state sector.

The application of close-to-nature silvicultural methods has obstacles that can be traced in the statistical analysis in this article. However, there are other important factors that are influencing, mostly hindering the process:

- The technical background of forestry, especially living traditions of forestry technology is lacking in actively applied close-to-nature methods. Even forest planning is challenged by the task of how to incorporate uneven-aged forests in the present planning protocol. (Frank 2014)

- Wild game damage is reported to be the most important (semi-)natural limiting factor of natural regeneration. Even though wild game management is experiencing a slow decline in terms of trophy quality and financial stability (Schiberna-Szalai, 2015), its lobbying ability is preventing it from fundamental changes. 
- The needs of society are usually a basis for arguments in discussions on the development of forestry practice. However, the public perception of nature is significantly different from what is advocated by environmental NGOs as the need of the society. Public opinion is mostly against clearcuts, and less sensitive about delicate differences of regeneration methods or silvicultural operations. (Kapócs-Horváth et al. 2012; Schiberna - Stark 2011, Folcz - Schiberna 2012)

- Lessons learned from afforestation programs suggest that private forest owners prefer easy and simple silvilcultural methods, as well as short rotation periods. Consequently, plantation forestry is more suitable for their short term economic goals and is also more suitable for their long term visions (Andrasevits - Schiberna 2005). Afforestations take place mostly in regions where site conditions also make these plantations the best choice.

- Rural development programs also showed that private forest owners are capable of applying more advanced silvicultural methods if they are coupled with subsidies. So the progress of close-to-nature forest management to a great extent depends on targeted forest policy measures.

To have a more realistic view of close-to-nature forest assets management, the possibility to investigate primary functions and regions in addition to looking at differences in sectors exists.

Controlling intentions along facts and knowing the pace and segments of changes would be an advantage when planning future measures.

\section{REFERENCES}

ANDRÁSEVITS Z. - SCHIBERNA E. (2005): Magánerd -gazdálkodás az agrárvállalkozásokban. [Private forestry in agrar enterprises] Gazdálkodás 49(2) : 28-37. (in Hungarian)

CSÉPÁNYI P. (2013): Az örökerd elvek szerinti és a hagyományos bükkgazdálkodás ökonómiai elemzése és összehasonlítása. [Economic analysis and comparison of beech forest management in traditional and continuous cover management regimes] In: Erdészettudományi közlemények 3(1) : 111-124. (in Hungarian)

FOLCZ Á. - SCHIBERNA E (2012): A magyar fogyasztói társadalom erd kkel kapcsolatos igényei és annak környezetgazdasági hatásai. [Requirements of the Hungarian consumer society towards forests and their effects on the environmental economy] In: Lett B. - Schiberna E. - Horváth S. Puskás L. - Stark M. (eds.): Mészáros Károly Emlékülés, Nyugat-magyarországi Egyetem Kiadó, 2012. pp. 17-29. (ISBN:978-963-334-058-5) (in Hungarian)

FRANK N. (2012): A szálaló és átalakító üzemmód erd m velési kérdései. [Sylvicultural issues of the transformation and continuous management system] In: Lett B. - Schiberna E. (eds.): Múlt és jöv III. A folyamatos erd borítás gazdálkodói szemmel. Nyugat-magyarországi Egyetem Kiadó, Sopron. (ISBN:978-963-334-085-1) : 6-12. (in Hungarian)

FRANK N. - VEPERDI G. - SCHIBERNA E. - GÁL J. (2014): Erd nevelési modelltáblák: múlt és jöv . [Forest tending models: past and present] In: Bidló A. - Horváth A. - Sz cs P. (eds.): IV. Kari Tudományos Konferencia: Konferencia kiadvány (ISBN:978-963-359-033-1) : 20-23. (in Hungarian)

GYÖNGYÖSSY P. (Ed.) (2012): Múlt és jöv IV. Tartamosság, természetszer ség, társadalmi kontroll. [Past and future IV. Sustainability, close-to-nature management, control by the society] Nyugatmagyarországi Egyetem Kiadó, Sopron (ISBN 978-963-334-081-3) : 244 p. (in Hungarian)

KAPócs-Horváth Zs. - HÉJJ B. - LetT B. - StARK M. - SChiberna E. (2012): A társadalom erd kkel kapcsolatos véleményének vizsgálata. [Investigating the opinion of the society about forests] In: Lett B. - Schiberna E. (eds.): Múlt és jöv III.: A folyamatos erd borítás gazdálkodói szemmel, Nyugat-magyarországi Egyetem Kiadó, Sopron. (ISBN:978-963-334-085-1) : 84-92. (in Hungarian) 
LetT B. - NAGY I. - PUSKÁS L. - STARK M. - HoRVÁth S. - HoRVÁth T. (eds.) (2009): Múlt és jöv . Kisparaszti szálalás a Vendvidéken. [Past and future: Small scale continuous cover forestry in the Vend area in Hungary] Soproni Fels oktatási Alapítvány, Sopron. (ISBN 978-963-06-7086-9) : 222 p. (in Hungarian)

LETT B. - NAGY I. - PUSKÁS L. - STARK M. - HORVÁTH S. - HORVÁTH T. (eds.) (2010): Múlt és jöv II. „Tarvágásból szálalásba”. A folyamatos erd borítás üzemmódjainak bevezetése, gyakorlata. [Past and future II. „From clearcut to selection system”.Introduction and practice of the management regimes of continuous cover forestry.] Szabó Vendel EV. (ISBN 978-963-06-9392-9) 206 p. (in Hungarian)

LETT B. - SCHIBERNA E. (eds.) (2012): Múlt és jöv III. A folyamatos erd borítás gazdálkodói szemmel. Természetközeli erd gazdálkodási módszerek tapasztalatai. [Past and future III. The selection system from the viewpoit of forest managers. Experiences of close-to-nature forest management practices.] Nyugat-magyarországi Egyetem Kiadó, Sopron (ISBN 978-963-334-085-1) : 104 p. (in Hungarian)

LETT B. - STARK M. (2013): Az erd vagyon-gazdálkodás szerkezetének változása (2000-2009/2010) [Change of the structure of forest resources management (2000-2009/2010)] In: Lett et al. (eds.) Mészáros Károly Emlékülés. 2013. június 18. Nyugat-magyarországi Egyetem Kiadó, Sopron (ISBN 978-963-334-058-5) : 63-85 (in Hungarian)

Lett B. - Schiberna E. - Stark M. - Horváth S. - Szabó Zs. (Eds) (2013): Mészáros Károly Emlékülés. 2013. június 18. Nyugat-magyarországi Egyetem Kiadó, Sopron (ISBN 978-963-334-058-5) : 154 p.

LETT B. - STARK M. (2014): A természetközeli erd vagyon-gazdálkodás regionális sajátosságai. [regional specifics od close-to-nature forest management] El adás kézirat. Mészáros Károly Emlékülés - IV. Erdész-ökonómus Találkozó, Sopron, 2014. június 13. (in Hungarian)

MAROSI GY. - JUHÁSZ I. (2014): Az átalakító és a szálaló üzemmódok költség - hozam viszonyai. [Costbenefit relations in transformation and continuous cover management regimes] El adás kézirat. Mészáros Károly Emlékülés - IV. Erdész-ökonómus Találkozó, Sopron, 2014. június 13. (in Hungarian)

SCHIBERNA E. - LETT B. - JUHÁSZ I. (2012): A folyamatos erd borítás ökonómiai értékelésének elvi kérdései. [Theoretical question of the economic valuation of continuous cover forestry] In: Erdészettudományi közlemények 2(1) : 7-19. (in Hungarian)

SCHIBERNA E. - STARK M. (2011): Erd pedagógia az erdészeti fels oktatásban. [Forest pedagogy in forestry higher education] In: Kováts-Németh Mária (ed.): Együtt a környezetért, Palatia Nyomda és Kiadó Kft. (ISBN:978-963-7692-35-2) : 203-220. (in Hungarian)

SCHIBERNA E. - SZALAI Á. (2015): A vadgazdálkodási ágazat gazdasági elemzése - Nemzeti kincsünk marad-e a gímszarvas? [Economic Analysis of Wild Game Management Sector in Hungary - Red Deer as National Heritage endangered] In: Lett B. -Schiberna E. - Jáger L. - Stark M. - Horváth S. (eds.): Tanulmánykötet Mészáros Károly tiszteletére. Nyugat-magyarországi Egyetem Kiadó, Sopron: (ISBN:978-963-334-242-8) : 73-81. (in Hungarian)

SOLYMOS R. (2000): Erd felújítás és -nevelés a természetközeli erd gazdálkodásban. [Forest regeneration and tending in close-to-nature forest management] Mez gazdasági Szaktudás Kiadó, Budapest: 286 p. (in Hungarian)

1996. évi LIV. törvény az erd r 1 és az erd védelmér 1 [Law No. LIV of 1996 on forests and their protection]

2009. évi XXXVII. törvény az erd $\mathrm{r} 1$, az erd védelmér 1 és az erd gazdálkodásról [Law No. XXXVII of 2009 on forests, on the protection and management of forests]

275/2004. (X. 8.) Korm. rendelet az európai közösségi jelent ség természetvédelmi rendeltetés területekr 1 (Natura2000) [Decree No. 275 of 2004 (X. 8.) of the Government on nature conservation areas of European Community importance]

\section{SOURCE OF DATA}

MgSzH Erdészeti Igazgatóság (2000; 2009; 2010): Beszámoló az erd sítésekr 1 és a fakitermelésekr 1 [Report on afforestations and cuttings] (in Hungarian) 
